\title{
Predatory Gall Midge (unofficial common name), Feltiella acarisuga (Vallot) (Insecta: Diptera: Cecidomyiidae) ${ }^{1}$
}

\author{
Ryan S. Osborne, Norman C. Leppla and Lance S. Osborne ${ }^{2}$
}

\section{Introduction}

The predatory gall midge, Feltiella acarisuga (Vallot), is one of the most effective and widespread natural enemies of spider mites (Tetranychidae) (Gagne 1995). It is a particularly important natural enemy of the twospotted spider mite, Tetranychus urticae Koch, in a number of cropping systems (Opit et al. 1997). F. acarisuga could be particularly useful for integrated pest management of spider mites that attack greenhouse crops (Gillespie et al. 1998).

\section{Synonymy}

\section{Cecidomyia acarisuga}

Mycodiplosis minuta

Therodiplosis persicae

T. beglarovi

Arthrocnodax rutherfordi

Feltiella tetranychi
F. davisi,

F. americana

F. ithacae

F. quadrata (Gagne 1995)

\section{Distribution}

The genus Feltiella is virtually cosmopolitan and contains eight species: F. acarisuga (worldwide, except for the Neotropical Region), F. pini (Felt) (North and Central America and West Indies), $F$. curtistylus Gagne (Brazil), F. occidentalis (Felt) (U.S.- California), F. acarivora (Zehnter) (Indonesia- Java), F. insularis (Felt) (eastern U.S., West Indies and Colombia), F. reducta Felt (northeastern U.S. - New York), and F. ligulata Gagne (Cape Verde Is.) (Gagne 1995). F. acarisuga is the most widely distributed species in the genus and is listed from the U.S., Canada, Finland, Germany, U.K., Switzerland, Italy, Morocco, Greece, Israel, India, Sri Lanka, Taiwan, Japan and New

1. This document is EENY-269, one of a series of Featured Creatures from the Entomology and Nematology Department, Florida Cooperative Extension Service, Institute of Food and Agricultural Sciences, University of Florida. Published: June 2002. This document is also available on Featured Creatures Website at http://creatures.ifas.ufl.edu. Please visit the EDIS Website at http://edis.ifas.ufl.edu.

2. Ryan S. Osborne, Norman C. Leppla, Entomology and Nematology Department, University of Florida, Gainesville and Lance S. Osborne, Entomology and Nematology Department, Mid-Florida REC, University of Florida, Apopka, FL.

The Institute of Food and Agricultural Sciences (IFAS) is an Equal Employment Opportunity - Affirmative Action Employer authorized to provide research, educational information and other services only to individuals and institutions that function without regard to race, creed, color, religion, age, disability, sex, sexual orientation, marital status, national origin, political opinions or affiliations. For information on obtaining other extension publications, contact your county Cooperative Extension Service office. Florida Cooperative Extension Service / Institute of Food and Agricultural Sciences / University of Florida / Larry R. Arrington, Interim Dean 
Zealand. It is the only species of Feltiella found throughout most of Europe and Asia.

\section{Description}

\section{Egg}

The shiny, translucent oblong eggs are deposited individually near prey mites on leaves. They are $0.1 \mathrm{x}$ $0.25 \mathrm{~mm}$ in size (Koppert 1997). The eggs hatch within two days after oviposition and the larvae immediately begin to feed.

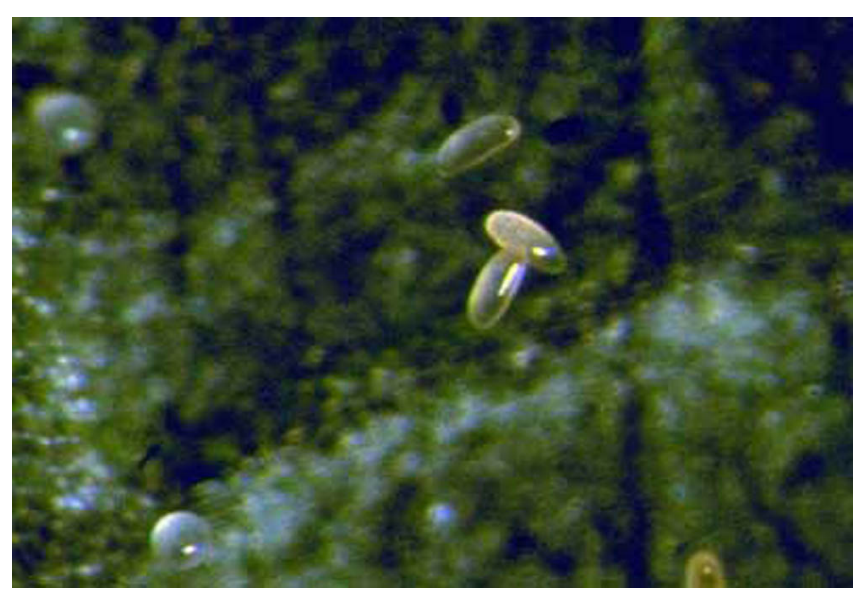

Figure 1. Eggs of the predatory gall-midge, Feltiella acarisuga (Vallot). Credits: David R. Gillespie, Agassiz

\section{Larva}

The orange-brown larvae vary in length from 0.2 to $2 \mathrm{~mm}$ during their four developmental instars (Koppert 1997). They forage for mites on leaves and feed for four to six days, depending on temperature, $\mathrm{RH}$ and the abundance of prey mites (Gillespie and Raworth 1999). They feed exclusively on all developmental stages of several species of spider mites. F. acarisuga larvae occur in populations as large as 160 per $\mathrm{cm} 2$ of eggplant leaf.

\section{Pupa}

The fluffy white, 1 to $1.5 \mathrm{~mm}$ long pupa requires four to six days to complete development and produce an adult (Koppert 1997). Pupation occurs mainly on the underside of a leaf next to a vein.

\section{Adult}

The adult $F$. acarisuga is a delicate pink-brown fly about $2 \mathrm{~mm}$ in length with long legs (Koppert

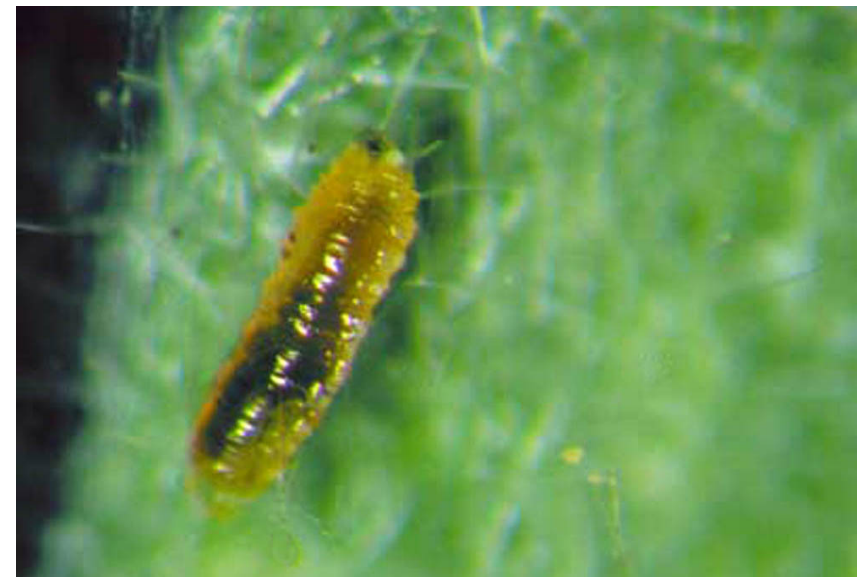

Figure 2. Larva of the predatory gall-midge, Feltiella acarisuga (Vallot). Credits: Lance S. Osborne, University of Florida

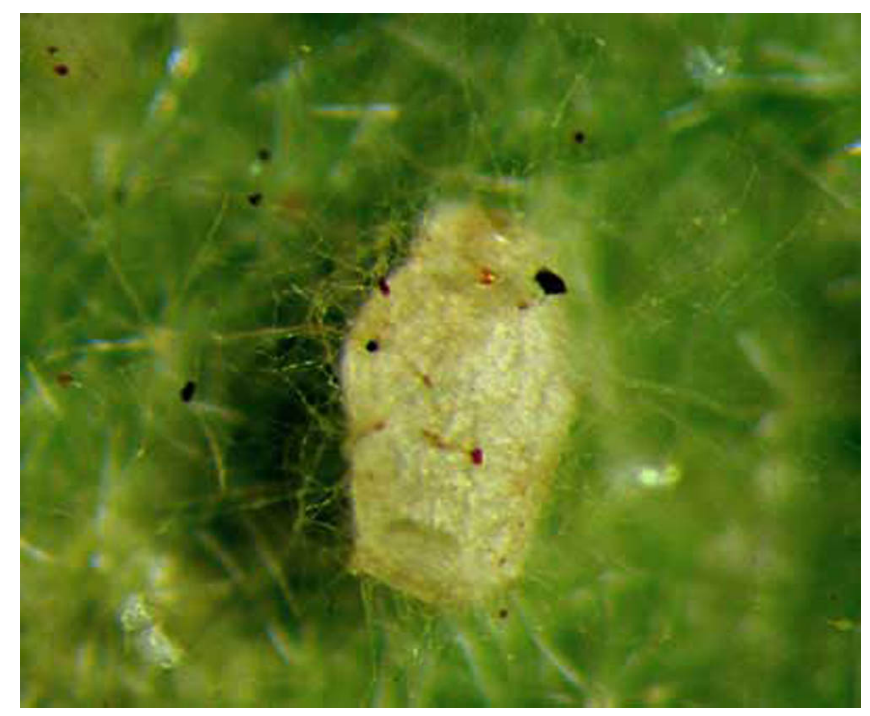

Figure 3. Pupa of the predatory gall-midge, Feltiella acarisuga (Vallot). Credits: Lance S. Osborne, University of Florida

1997). Females have a five day life span and produce about 30 eggs. Males do not live as long as females. The sex ratio is about 1:1. Adult $F$. acarisuga are not predaceous but drink water and nectar.

\section{Life Cycle}

In climates without extremely dry or cold seasons, every stage of $F$. acarisuga is present year-round. Feltiella spp. apparently develop from egg to egg in 26 to 33 days, averaging around 29 days (Sharaf 1984); however, F. acarisuga requires about 15 days (Gillespie et al. 1998). Reproduction and development occur at $15-25^{\circ} \mathrm{C}$. Eggs and larvae do not survive above $30^{\circ} \mathrm{C}$ or below $30 \% \mathrm{RH}$. At least $50 \% \mathrm{RH}$ is required for a normal rate of development. 


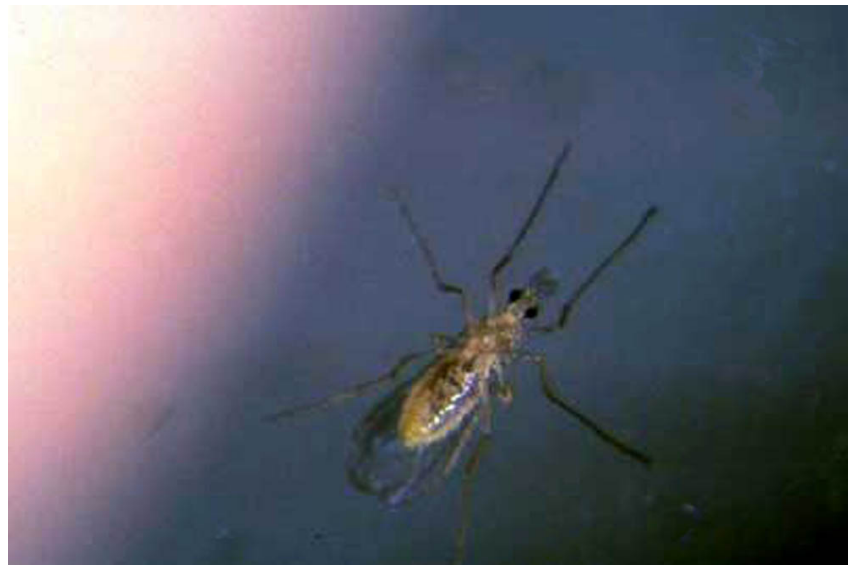

Figure 4. Adult of the predatory gall-midge, Feltiella acarisuga (Vallot). Credits: David R. Gillespie, Agassiz

The optimum temperature and $\mathrm{RH}$ combination is about $20^{\circ} \mathrm{C}$ and $90 \% \mathrm{RH}$. However, with an abundance of prey, the level of predation remains constant over the developmental range of temperature and RH (Gillespie et al. 1998). If prey populations are sub-optimal, larvae can survive by pupating at a smaller size. Larvae also can survive for several days without prey.

\section{Effectiveness}

Feltiella acarisuga can be used to manage spider mite populations in a variety of greenhouse and field crops, especially when incorporated into a bio-intensive IPM program. In eggplant, for example, $F$. acarisuga has appeared naturally and reduced spider mite numbers by more than $40 \%$ (Sharaf 1984). Each midge larva can consume an average of least 15 adult mites, 30 mixed developmental stages, or 80 eggs per day. Weekly releases of 1000 individuals per ha have been extremely effective for controlling spider mites on tomato, pepper and cucumber (Gillespie et al. 1998). In addition, $F$. acarisuga (sold as Therodiplosis persicae) is being used to manage spider mites on strawberries and various ornamental crops. It is recommended that 200-1000 individuals per ha be released weekly as a trial rate for growers. The weekly release rate is approximately doubled for heavy infestations, 2,500 adults per ha for six successive weeks (Biobest 1999).

It is highly advised that $F$. acarisuga be released in combination with the predaceous mite, Phytoseulus persimilis, a well-established natural enemy used to control spider mites. F. acarisuga is more mobile as an adult than is the predatory mite and, once established, eats at least five times as many spider mites (Biobest 1999). However, P. persimilis should not be released where $F$. acarisuga is becoming established because they are known to eat midge eggs if prey is limited (Gillespie 1998).

\section{Commercial Availability and Use}

F. acarisuga pupae are commercially available from several producers and suppliers of natural enemies (http://www.anbp.org/ and http://www.cdpr.ca.gov/docs/ipminov/ben_supp/ contents.htm). Pupae are shipped on leaves or an inert substance in various containers, such as 1-liter pots. Pots are placed in the crop on the ground at the beginning of rows and their lids are pierced to release the adult midges. It is best if the midges are released near concentrations of spider mites. To establish, $F$. acarisuga requires fairly large prey populations (Gillespie and Raworth 1999). The pots should be stored in the dark for no more than two days at $10-15^{\circ} \mathrm{C}$ (Koppert 1997). Adults should be released from containers every 24 hours, late at night or early in the morning because of the cooler and more humid conditions. The RH should be kept above $80 \%$, if possible (Gillespie and Raworth 1999).

It is essential to avoid non-target side effects of chemical pesticides, such as Thiodan, Diazinon, and Kelthane; however, most fungicides are safe to use with $F$. acarisuga (Gillespie and Raworth 1999). Sulfur products used as dusts or sprays do not cause mortality in larvae but females avoid laying eggs on treated plants. Another concern is parasitization of $F$. acarisuga larvae by Aphanogmus floridanus, potentially a very abundant parasitoid during warmer months. However, if necessary, releases can be timed to avoid the parasitoid because unlike the parasitoid $F$. acarisuga does not diapause during the cooler months. F. acarisuga parasitized by A. floridanus have pupal cases with characteristic round emergence holes.

\section{Selected References}

Biobest NV. (1999). Therodiplosis persicae. Belgium. http://www.biobest.be/ (30 May 2002). 
Gagne RJ. 1995. Revision of Tetranychid

(Acarina) mite predators of the genus Feltiella

(Diptera: Cecidomyiidae). Annals of the

Entomological Society of America 88:16-30.

Gillespie DR, Raworth DA. 1999. Biological Control of Twospotted Spider Mites on Greenhouse Vegetable Crops. Agriculture and Agri-Food Canada. P. 30-32.

Gillespie DR, Roitberg B, Basalyga E, Johnstone M, Opit G, Rodgers J, Sawyer N. 1998. Biology and application of Feltiella acarisuga (Vallot) (Diptera: Cecidomyiidae) for biological control of twospotted spider mites on greenhouse vegetable crops. Pacific Agri-Food Research Centre (Agassiz)Technical Report, No. 145. Agriculture and Agri-Food Canada.

Koppert BV. (1997). SPIDEND. Feltiella acarisuga. Netherlands. http://www.koppert.nl/ (30 May 2002).

Opit GP, Roitberg B, Gillespie DR. 1997. The functional response and prey preference of Feltiella acarisuga (Vallot) (Diptera: Cecidomiidae) for two of its prey: male and female twospotted spider mites, Tetranychus urticae Koch (Acari: Tetranychiidae). Canadian Entomologist 129: 221-227.

Osborne LS, Ehler LE, Nechols JR. (July 1999). Biological control of the twospotted spider mite in greenhouses.

http://www.mrec.ifas.ufl.edu/lso/SpMite/b853a1.htm (13 September 2002).

Sharaf NS. 1984. Studies on natural enemies of tetranychid mites infesting eggplant in the Jordan Valley. Zeitschrift fur Angewandte Entomologie. 98:527-533. 